\title{
HIV-1 latency in activated T-cells
}

\author{
Ben Berkhout \\ From Frontiers of Retrovirology: Complex retroviruses, retroelements and their hosts \\ Cambridge, UK. 16-18 September 2013
}

HIV-1 latency remains a formidable barrier towards virus eradication as therapeutic attempts to purge these reservoirs are so far unsuccessful. The pool of transcriptionally silent proviruses is established early in infection and persists for a lifetime, even when viral loads are suppressed below detection levels using anti-retroviral therapy. Upon therapy interruption the reservoir can re-establish systemic infection. Different cellular reservoirs that harbor latent provirus have been described. In this study we demonstrate that HIV-1 can also establish a silent integration in actively proliferating primary $\mathrm{T}$ lymphocytes. Co-culturing of these proliferating $\mathrm{T}$ lymphocytes with dendritic cells (DCs) activated the provirus from latency. Activation did not involve DC-mediated C-type lectin DC-SIGN signaling or TCR-stimulation but was mediated by DC-secreted component(s) and cell-cell interaction between DC and T lymphocyte that could be inhibited by blocking ICAM-1 dependent adhesion. These results imply that circulating DCs could purge HIV-1 from latency and re-initiate virus replication. Moreover, our data show that viral latency can be established early after infection and supports the idea that actively proliferating $\mathrm{T}$ lymphocytes with an effector phenotype contribute to the latent viral reservoir. Unraveling this physiologically relevant purging mechanism could provide useful information for the development of new therapeutic strategies that aim at the eradication of HIV-1 reservoirs.

Published: 19 September 2013

doi:10.1186/1742-4690-10-S1-022

Cite this article as: Berkhout: HIV-1 latency in activated T-cells.

Retrovirology 2013 10(Suppl 1):O22.

Academic Medical Center (AMC), University of Amsterdam, Netherlands

Submit your next manuscript to BioMed Central and take full advantage of:

- Convenient online submission

- Thorough peer review

- No space constraints or color figure charges

- Immediate publication on acceptance

- Inclusion in PubMed, CAS, Scopus and Google Scholar

- Research which is freely available for redistribution

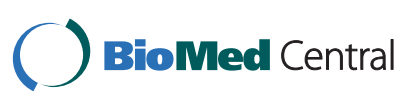

